\title{
Effect of protein supplementation on yield and milk composition of F1 Holstein $x$ Zebu cows kept in deferred pasture of brachiaria grass
}

[Efeito da suplementação de proteína na produção e na composição do leite de F1 vacas Holandês $x$ Zebu mantidas em pasto diferido de capim-braquiária]

T.M.R. Lima $^{1}$, J.R.M. Ruas ${ }^{1}$, V.M. Gomes ${ }^{1}$, V.R. Rocha Júnior ${ }^{1}$, F.P. Monção ${ }^{1 *}$, C.B. Silva ${ }^{1}$, J.P.S. Rigueira ${ }^{1}$, C.C.S. Carvalho ${ }^{1}$, E.C.J. Sales ${ }^{1}$, L.D.A. Rufino ${ }^{2}$, E.A. Silva ${ }^{3}$, D.S. Queiroz ${ }^{3}$, A.M.S. Alencar ${ }^{1}$

${ }^{1}$ Universidade Estadual de Montes Claros - Janaúba, MG

${ }^{2}$ EPAMIG Norte - Montes Claros, MG

${ }^{3}$ EPAMIG Triângulo Mineiro - Uberaba, MG

\begin{abstract}
The objective of this study was to evaluate different supplementation strategies concentrated to F1 Holstein x Zebu lactating cows managed in deferred signal grass pasture on the yield and composition of milk and body weight gain. Thirty six F1 Holstein x Zebu cows with an average lactation period of $267 \pm$ 10 days, mean body weight of $548 \pm 19 \mathrm{~kg}$ were used following a completely randomized design in a 4 x 5 factorial scheme, being four feeding strategies and five days under evaluation. The treatments consisted of four nutritional strategies: deferred pasture as a source of roughage without supplementation (PDSS); deferred pasture as a source of roughage with protein supplement offer (PDCS); deferred pasture supplemented with 15 kilos of corn silage (natural base) $+1,200$ grams of protein supplement (PDSP) and corn silage $($ ad libitum $)+700$ grams of protein supplement (SMP). There was no interaction $(\mathrm{P}>0.05)$ between the nutritional plans and days under evaluation for any of the variables. It was found that cows fed SMP showed milk production $26.06 \%$ higher than the other nutritional plans (mean of $11.46 \mathrm{~kg} / \mathrm{day}$ ). F1 Holstein/Zebu cows handled in deferred pasture in a traditional way supplemented with protein maintains milk yield.
\end{abstract}

Keywords: pasture deferment, Urocloa decumbens, crossbred cows, milk production, milk urea nitrogen

\section{RESUMO}

Objetivou-se avaliar diferentes planos nutricionais para vacas F1 Holandês/Zebu mantidas em pasto diferido de capim-braquiária sobre a produção e a composição do leite e no ganho em peso corporal. Foram utilizadas 36 vacas F1 Holandês/Zebu com período médio de lactação de $267 \pm 10$ dias, peso corporal médio de $548 \pm 19 \mathrm{~kg}$, seguindo o delineamento inteiramente ao acaso, em esquema fatorial $4 x$ 5 , sendo quatro estratégias de alimentação e cinco dias em avaliação. Os tratamentos consistiram de quatro planos nutricionais: pasto diferida como fonte de forragem sem suplementação (PDSS); pastagem diferida como fonte de forragem com oferta de suplemento de proteico (PDCS); pasto diferido suplementado com 15 quilos de silagem de milho (base natural) +1.200 gramas de suplemento proteico (PDSP) e silagem de milho (ad libitum) +700 gramas de suplemento de proteína (SMP). Verificou-se que as vacas alimentadas com SMP apresentaram produção de leite 26,06\% superior aos demais planos nutricionais (média de 11,46kg/dia). Vacas F1 Holandês/Zebu tratadas em pastagem diferida de maneira tradicional, suplementada com proteina, mantêm o rendimento de leite.

Palavras-chave: pasto diferido, Urocloa decumbens, vacas mestiças, produção de leite, nitrogênio ureico no leite

Recebido em 30 de junho de 2020

Aceito em 18 de novembro de 2020

*Autor para correspondência (corresponding author)

E-mail: moncaomoncao@yahoo.com.br 


\section{INTRODUCTION}

Cultivated pastures form the basis for milk production and, when well managed, are capable of sustaining satisfactory levels of milk production, especially at the most favorable times of the year (Teixeira et al., 2019; Santana et al., 2019; Borges et al., 2020). However, throughout the year, forage production fluctuates according to climatic conditions. Consequently, the quality of the pasture is an important factor that influences the productivity of the grazing dairy herd and can be aggravated during the dry season of the year. The deferral of the use of pasture is a technique that consists in selecting certain areas of the property and excluding them from grazing, usually carried out at the end of the water period, guaranteeing forage production for the dry season, minimizing the effects of seasonality in the production of forage (Santos et al., 2009).

In beef cattle, the practice of using protein supplements associated with deferred pasture is common, and has positive results for weight gain, since it improves the digestibility of the pasture forage mass and forage intake (Sampaio et al., 2017). Currently, for dairy cows in Brazil, it is observed that about $90 \%$ of concentrated supplements have between 20 and $22 \%$ of crude protein, and the most common recommendation is to provide one $\mathrm{kg}$ of concentrate for every three $\mathrm{kg}$ of milk produced (Sheahan et al., 2013; Teixeira et al., 2019). However, only good quality pasture is generally not enough to promote the full productive potential of highyielding cows, since it does not meet the entire requirement of the dairy animal, especially in terms of energy (Teixeira et al., 2019). In Brazil, about $80 \%$ of the total volume of milk is produced by crossbred Holstein/Zebu cows using tropical forages associated with concentrate supplementation strategies (Salgado et al., 2016; Borges et al., 2020). Crossbred cows reared under forage-based milk production systems are flexible in terms of milk production during the summer due to their adaptability and hardiness (Borges et al., 2020).

Therefore, it is necessary to adapt the diet through concentrated supplementation, which can favor the rate of degradation of the food and optimize the production of microbial protein. One of the roles of energy and/or protein supplementation is to add nutrients that cannot be obtained in sufficient quantity from the pasture. However, the excess of supplements can depress the forage intake with substitutive effect without any advantages in the intake of nutritents (Sheahan et al., 2013; Silva et al., 2017). Furthermore, excess supplementation in the diet causes metabolic disorders (i.e. ruminal acidosis), which affects the animals' performance. Thus, the rational supply of protein supplements is essential to enable supplementation, requiring the development of strategies to maximize the use of the supplement and forage intake (Danes et al., 2013). In this context, the objective of this study was to evaluate different strategies of protein supplementation (nutritional plans) on the productive performance and milk composition of F1 Holstein x Zebu cows kept in deferred pasture of brachiaria grass.

\section{MATERIAL AND METHODS}

All animal care and handling procedures were approved by the Animal Care and Use Committee of the Universidade Estadual de Montes Claros, Brazil (protocol CEBEAUnimontes 150/2017). The experiment was carried out at EPAMIG's Experimental farm in the city of Felixlândia, Minas Gerais, Brazil

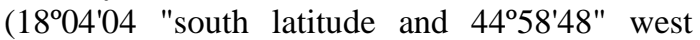
longitude, at an average altitude of $616 \mathrm{~m})$. The region's climate is classified as AW (wet tropical savanna, with dry winter and rainy summer), according to the Köppen-Geiger classification. The average annual rainfall is $1,126 \mathrm{~mm}$.

The experiment was carried out in the winter weather season. In Central Brazil, the winter season runs from July to November. The adaptation of animals to pasture, management and supplements lasted 14 days and 36 days for data collection and sampling. The experimental area formed with Urochloa (Syn. Brachiaria) decumbens cv. Basilisk was divided into 27 paddocks (1 ha each). Each paddock has drinking fountains (1,500 liters) and troughs for supplement (1 linear meter per animal), allowing continuous grazing. Prior to the beginning of the experiment, the paddocks were sealed for 60 days. To ensure adequate forage mass for the animals, nitrogen fertilization was carried out at the beginning and end of the summer season. 
The nitrogen source used was urea and $50 \mathrm{~kg} / \mathrm{ha}$ of $\mathrm{N}$ were applied in each application. Thirty-two $F 1$ Holstein $x$ Zebu cows in the final third of lactation of $267 \pm 10$ days, average body weight of $548 \pm 19 \mathrm{~kg}$ and average age of 7.4 years were used to evaluate the performance and composition of milk. The animals were identified individually by ear tag. The grazing method adopted was the continuous. A mass supply criterion and similar leaf supply between treatments were adopted. To keep the supply of similar and homogeneous forage available between the paddocks, the "put and take" method was used (Mott and Lucas, 1952), using animals with similar body weight, housed in paddocks attached to those used in the experiment. The strategies used were: Deferred pasture as a source of roughage without supplementation (PDSS); deferred pasture as a source of roughage with protein supplement offer (PDCS); deferred pasture supplemented with 15 kilos of corn silage (natural base) $+1,200$ grams of protein supplement (PDSP) and corn silage (ad libitum) +700 grams of protein supplement (SMP).

The cows were milked mechanically at 7 am and $2 \mathrm{pm}$ with calf at the foot. After milking, all cows received supplement concentrate in a 1:3 ratio, where $1 \mathrm{~kg}$ of concentrate was provided for each $3 \mathrm{~kg}$ of milk produced above the initial $5 \mathrm{~kg}$. This commercial concentrated supplement was different from that used in supplementation strategies in pasture and feedlot (NUTRILAC®, Agroquima, Unaí, Minas Gerais, Brazil). The concentrated supplement NUTRILAC® was supplied individually to the animals in wooden troughs (1 linear meter) coupled to the lateral pipeline of the milking line. After each milking, the animals were handled in each paddock that had collective waterers and individual feeders.

The animals that received corn silage as an exclusive source of roughage associated with a concentrated supplement were kept in feedlot in individual stalls $\left(5 \mathrm{~m}^{2}\right)$ with feeders and drinkers. Before delivery, the leftovers of the supplied were collected the day before. The animals that received the PDSP strategy were first milked and, after the morning milking, they were confined for corn silage intake $(15 \mathrm{~kg} / \mathrm{animal} /$ day of corn silage mixed with $700 \mathrm{~g} / \mathrm{animal}$ protein supplement). After the afternoon milking, the animals in the PDSP treatment received
$500 \mathrm{~g} / \mathrm{animal}$ of protein supplement to close the $1,200 \mathrm{~g} / \mathrm{animal} / \mathrm{day}$. The corn was grown on the experimental farm and ensiled in a surface silo after 90 days of planting. The silo was opened after 100 days of closed.

To estimate the pasture forage mass, samples of forage were collected every 15 days using a square frame $\left(0.25 \mathrm{~m}^{2}\right)$. All the forage contained within the frame was cut close to the ground and weighed. The estimated forage mass availability in each paddock was an average of $5.22 \mathrm{t} \mathrm{ha}^{-1}$ of dry matter at the beginning of the experiment. During the forage collection, the pasture was sampled by means of manual grazing simulation using the "hand-plucking" method. Samples of the whole plant collected in the frame and by grazing simulation, concentrated supplements and corn silage were analyzed for drymatter (DM) (INCT - CA G-003/1), ash (INCT - CAm -001/1), crude protein (PB) (INCT - CA N001/1), ether extract (EE) (INCT- CA G-004/1), neutral detergent fiber (NDF) (INCT - CA F 002/1) and its corrections for ash (INCT - CAm002/1) and protein (INCT - CA N-004/1), acid detergent fiber (ADF) (INCT - CA F-004/1), lignin (INCT-CA F-005/1) and non-fibrous carbohydrates $(\mathrm{NFC}=100$ - ash - EE - NDFap CP) according to methods recommended by Detmann et al. (2012). Total digestible nutrients (TDN) were estimated according to the NRC (Nutrient..., 2001) (Table 1).

The milk yield (MY) was measured individually twice daily milkings for 7 a.m to 2 p.m, and twice a week for five weeks with calf presence to stimulate milk letdown. After milking, the calves remained with the mothers to feed residual milk. Milk yield corrected for the fat content (FC) $3.5 \%$ using the equation proposed by Sklan et al. (1992): $\mathrm{mY} 3.5 \%=\mathrm{mY} \times(0.432+0.163 \times$ FC $)$. Samples of $50 \mathrm{~mL}$ of milk were collected directly from the automatic meter, with a composite sample being made proportional to the morning and afternoon productions, once a week always on the same day. The samples were placed in containers containing bromopol ${ }^{\circledR}$ preservative (2-bromine, 2-nitropropane 1,3-diol) to determine the levels of fat, protein, lactose, defatted dry extract (DDE), somatic cell count (SCC), total solids, milk urea nitrogen (MUN) and casein. 
Table 1. Chemical composition of deferred pasture, corn silage and concentrate supplement used in the experiment

\begin{tabular}{|c|c|c|c|c|c|}
\hline \multirow[b]{2}{*}{ Item $^{1}$} & \multicolumn{5}{|c|}{ Ingredients (g/kg DM) } \\
\hline & $\begin{array}{l}\text { Deferred } \\
\text { Pasture }^{2} \\
\end{array}$ & $\begin{array}{c}\text { Deferred Pasture } \\
3\end{array}$ & $\begin{array}{c}\text { Corn } \\
\text { silage }\end{array}$ & $\begin{array}{l}\text { Concentrate } \\
\text { supplement }\end{array}$ & Nutrilac $\AA^{4}$ \\
\hline Dry matter & 644 & 663 & 316 & 788 & 861 \\
\hline Crude protein & 33 & 47 & 70 & 1000 & 236 \\
\hline Ether extract & 9 & 10 & 52 & 47 & 74.5 \\
\hline NDFap & 697 & 624 & 424.8 & 159 & 318 \\
\hline $\mathrm{ADF}$ & 456 & 400 & 241 & 27 & 41 \\
\hline Lignin & 61 & 31 & 34 & 5 & 2 \\
\hline Total digestible nutrientes ${ }^{1}$ & 385 & 453 & 633 & 753 & 702 \\
\hline In vitro digestibility of dry matter* & 524 & 552 & 596 & 920 & 931 \\
\hline In vitro digestibility of crude protein* & 362 & 451 & 562 & 956 & 945 \\
\hline In vitro digestibility of NDFap* & 456 & 576 & 488 & 920 & 900 \\
\hline
\end{tabular}

${ }^{1}$ DM - Dry matter; NDFap - neutral detergent fiber corrected for ash and protein; ADF - acid detergent fiber. * Estimated by Valadares Filho et al., 2016

2 Pasture deferred from Urochloa (Syn. Brachiaria) decumbens cv. Basilisk - Whole plant

${ }^{3}$ Pasture deferred from Urochloa (Syn. Brachiaria) decumbens cv. Basilisk - Simulated grazing

${ }^{4}$ Commercial rations for dairy cattle.

The percentage of fat, protein content, lactose, defatted dry extract, milk urea nitrogen (MUN), somatic cell count (SCC) and casein by the infrared method by the flow cytometry method. In the assessment of the body condition score, the 1 to 5-point scale with 0.10 -point intervals was used, in which 1 represents a very lean cow and 5 a very fat cow (adapted from Mishra et al., 2016).

Due to the homogeneity of the animals' body weight, lactation phase, age and forage supply, a completely randomized design in a 4 x 5 factorial scheme was used, with four supplementation strategies and five weeks of evaluation. Each animal kept in the individual stall or paddock was considered as an experimental unit (nine experimental units for each treatment). The data were submitted to analysis of variance using the GLM procedure of SAS, version 9.0 (SAS Institute, Inc., Cary, NC, USA). Data normality (Shapiro-Wilk test at $5 \%$ probability) was verified by the UNIVARIATE procedure of SAS. The statistical model used for analyzes was $\hat{\mathrm{Y}}_{\mathrm{ijk}}=\mu+\mathrm{T}_{\mathrm{i}}+\mathrm{W}_{\mathrm{j}}, \mathrm{T}_{\mathrm{i}} \times \mathrm{W}_{\mathrm{j}}+\varepsilon_{\mathrm{ijk}}$, in which $\mathrm{y}_{\mathrm{ij}}$ represents the observation to treatment $\left(\mathrm{T}_{\mathrm{i}}\right)$ (with $\mathrm{i}=1,2,3$ and 4) in the animal $\mathrm{k}$ (with $\mathrm{k}=1,2$, $3 \ldots, 9), \mathrm{W}_{\mathrm{j}}$ represents the observation to Semana (with $\mathrm{J}=1,2,3,4$ and 5); $\mathrm{T}_{\mathrm{i}} \times \mathrm{W}_{\mathrm{j}}$ it is the effect of the interaction; $\mu$ it is general mean and eijk is the experimental error associated with all observations, independent, which by hypothesis has normal distribution with zero mean and variance $\delta_{2}$. Supplementation strategies (treatments) and interactions when significant by the F text were compared using the SNK test. The evaluation weeks were submitted to the study of regression analyzes using the REG of SAS software procedure (SAS Institute Inc., Cary, NC, USA). Differences were considered significant when $\alpha=0.05$.

\section{RESULTS AND DISCUSSION}

There was no interaction $(\mathrm{P}>0.05)$ between nutritional plans and days under evaluation for any of the variables evaluated. Therefore, the factors were presented and discussed in isolation. Among the nutritional plans, it was found that cows fed corn silage supplemented with $700 \mathrm{~g}$ of protein concentrate (SMP) showed milk production $26.06 \%$ higher than the other nutritional plans (mean of $11.46 \mathrm{~kg} /$ day). For the $3.5 \%$ fat-corrected milk yield, this increase was $32.35 \%$ for SMP in relation to the other treatments (mean of $12.17 \mathrm{~kg} /$ day; Table 2).

According to NRC (Nutrient..., 2001), the nutrients intake is one of the main factors that affect the performance of animals. In this research, the chemical composition of corn silage was better compared to deferred pasture (Table 1). With this, probably, the consumption of energy and protein was higher in the animals that received the diet based on SMP, which favored the greater production of milk in relation to the 
animals kept in deferred pasture. The pasture deferral technique is a low-cost strategy that aims to reserve the forage to be consumed in the period of lack of forage. Thus, depending on the time of deferral, the plant reaches physiological maturity, accumulating fibrous carbohydrates, with less digestibility and with less food value (Monção et al., 2019, 2020).

Table 2. Productive performance of F1 1/2 Holstein x 1/2 Zebu cows fed different nutritional plans

\begin{tabular}{|c|c|c|c|c|c|c|}
\hline \multirow{2}{*}{ Item } & \multicolumn{4}{|c|}{ Nutritional plans } & \multirow{2}{*}{$\mathrm{CV}(\%)$} & \multirow{2}{*}{ P-value } \\
\hline & PDSS & PDCS & PDSP & SMP & & \\
\hline Milk yield, kg/day & $10.62 b$ & $12.25 b$ & $11.51 \mathrm{~b}$ & $15.50 \mathrm{a}$ & 28.08 & $<0.01$ \\
\hline $3.5 \%$ fat-corrected milk yield, $\mathrm{kg} /$ day & $11.37 \mathrm{~b}$ & $13.05 \mathrm{~b}$ & $12.10 \mathrm{~b}$ & $17.99 \mathrm{a}$ & 30.45 & $<0.01$ \\
\hline
\end{tabular}

Means followed by different lowercase letters on the line differ by the SNK test $(\mathrm{P}<0.05)$.

PDSS - Deferred pasture as a source of roughage without supplementation; PDCS - Deferred pasture as a source of roughage with protein supplement offer; PDSP - deferred pasture supplemented with 15 kilos of corn silage (natural base) + 1,200 grams of protein supplement; SMP - corn silage (ad libitum) +700 grams of protein supplement.

CV-Coefficient of variation

P- Probability

Thus, the lower productivity of cows kept in deferred grass pasture is justified. Despite the inclusion of $15 \mathrm{~kg}$ of corn silage in the PDSP nutritional plan, this amount $(4.74 \mathrm{~kg}$ of DM) was not sufficient to meet the nutritional requirement of the animals for milk production above $11.46 \mathrm{~kg} /$ day. Despite the lower productivity of milk using deferred pasture in relation to keeping animals in confinement receiving SMP, brachiaria grass when deferred for 60 days and associated with protein mineral supplementation proved to be promising as a nutritional source for F1 Holstein/Zebu cows in initial third of lactation. This is due to the better leaf: stem ratio of this forage that was little changed due to the time of deferral.
In general, there was no effect $(\mathrm{P}>0.05)$ of the days being evaluated on milk yield and $3.5 \%$ fatcorrected milk yield (Table 3 ). This was because the variation in production was low within the nutritional plans. Only in the PDSS nutritional plan, a reduction of $0.10 \mathrm{~kg} /$ day was observed for each day that increased postpartum. This shows that even in late lactation stage F1 Holstein/Zebu cows, deferred pasture as the only nutritional source is not sufficient to meet the nutritional demand of animals over time and supplementation is mandatory. In addition, the lactation stage also affects milk yield (Santana et al., 2020).

Table 3. Productive performance of F1 1/2 Holstein x $1 / 2$ Zebu cows fed different nutritional plans and days under evaluation

\begin{tabular}{|c|c|c|c|c|c|c|c|c|}
\hline \multirow{2}{*}{ Item } & \multicolumn{6}{|c|}{ Days under evaluation } & \multirow{2}{*}{$\mathrm{CV}(\%)$} & \multirow{2}{*}{ P-value } \\
\hline & 1 & 8 & 15 & 22 & 29 & 36 & & \\
\hline \multicolumn{9}{|c|}{ Milk yield, $\mathrm{kg} / \mathrm{day}$} \\
\hline PDSS $^{1}$ & 12.38 & 11.54 & 11.01 & 10.40 & 9.36 & 9.05 & 24.28 & $<0.01$ \\
\hline PDCS & 12.45 & 12.82 & 13.26 & 12.41 & 11.37 & 11.17 & 42.91 & NS \\
\hline PDSP & 11.94 & 11.94 & 12.34 & 11.12 & 10.44 & 11.27 & 21.27 & NS \\
\hline SMP & 14.42 & 17.30 & 15.49 & 15.09 & 15.12 & 15.57 & 18.85 & NS \\
\hline \multicolumn{9}{|c|}{$3.5 \%$ fat-corrected milk yield, $\mathrm{kg} /$ day } \\
\hline $\mathrm{PDSS}^{2}$ & 13.34 & 12.16 & 11.7 & 11.26 & 10.03 & 9.77 & 23.55 & $<0.01$ \\
\hline PDCS & 13.71 & 13.81 & 14.09 & 13.47 & 11.72 & 11.52 & 47.52 & NS \\
\hline PDSP & 12.84 & 12.21 & 12.97 & 11.67 & 10.88 & 11.89 & 21.91 & NS \\
\hline SMP & 17.17 & 20.57 & 18.00 & 16.79 & 17.48 & 17.95 & 22.36 & NS \\
\hline
\end{tabular}

PDSS - Deferred pasture as a source of roughage without supplementation; PDCS - Deferred pasture as a source of roughage with protein supplement offer; PDSP - deferred pasture supplemented with 15 kilos of corn silage (natural base) $+1,200$ grams of protein supplement; SMP - corn silage (ad libitum) +700 grams of protein supplement.

${ }^{1} \hat{Y}=12.42-0.10 X, R^{2}=0.99 ;{ }^{2} \hat{Y}=13.23-0.10 X, R^{2}=0.97$

NS: not significant.

CV- Coefficient of variation

P- Probability 
The milk composition can change due to the influence of diet. According to Wittwer (2000), the constituents of milk that can modify their levels are fat and protein. Fat can vary from 2 to 3 percentage units, while the variation in protein content is much smaller, ranging from 0.3 to
$0.4 \%$. There was a difference $(\mathrm{P}<0.01)$ between nutritional plans on milk composition. SMP-fed cows had higher concentrations of protein, fat, defatted dry extract, total dry extract and milk urea nitrogen compared to other treatments (Table 4).

Table 4. Milk composition of F1 1/2 Holstein x $1 / 2$ Zebu cows fed different nutritional plans

\begin{tabular}{lcccccc}
\hline \multirow{2}{*}{ Item } & \multicolumn{9}{c}{ Nutritional plans } & \multirow{2}{*}{ CV (\%) } & P-value \\
\cline { 2 - 6 } & PDSS & PDCS & PDSP & SMP & & \\
\hline Protein, \% & $3.00 \mathrm{c}$ & $3.24 \mathrm{ab}$ & $3.21 \mathrm{~b}$ & $3.34 \mathrm{a}$ & 8.18 & $<0.01$ \\
Fat, \% & $3.96 \mathrm{~b}$ & $3.85 \mathrm{~b}$ & $3.81 \mathrm{~b}$ & $4.48 \mathrm{a}$ & 16.07 & $<0.01$ \\
Lactose, \% & $4.63 \mathrm{a}$ & $4.54 \mathrm{~b}$ & $4.48 \mathrm{~b}$ & $4.70 \mathrm{a}$ & 4.12 & $<0.01$ \\
Defatted dry extract, \% & $8.66 \mathrm{~b}$ & $8.77 \mathrm{~b}$ & $8.71 \mathrm{~b}$ & $9.00 \mathrm{a}$ & 4.01 & $<0.01$ \\
Total dry extract, \% & $12.59 \mathrm{~b}$ & $12.62 \mathrm{~b}$ & $12.51 \mathrm{~b}$ & $13.49 \mathrm{a}$ & 5.67 & $<0.01$ \\
Milk urea nitrogen, mg/dL & $7.32 \mathrm{~d}$ & $8.89 \mathrm{c}$ & $10.46 \mathrm{~b}$ & $12.23 \mathrm{a}$ & 25.98 & $<0.01$ \\
Somatic cell count, & 102.50 & 96.42 & 119.36 & 167.81 & 21.43 & $>0.05$ \\
X thousand cells/mL & & & & & & \\
\hline
\end{tabular}

Means followed by different lowercase letters on the line differ by the SNK test $(\mathrm{P}<0.05)$.

PDSS - Deferred pasture as a source of roughage without supplementation; PDCS - Deferred pasture as a source of roughage with protein supplement offer; PDSP - deferred pasture supplemented with 15 kilos of corn silage (natural base) $+1,200$ grams of protein supplement; SMP - corn silage (ad libitum) + 700 grams of protein supplement.

$\mathrm{CV}$ - Coefficient of variation

P- Probability

For fat concentration, it was found that milk from cows that received more concentrated corn silage showed a higher percentage $(\mathrm{P}<0.05)$ compared to milk from cows from other treatments, which were similar to each other. The fat content in milk is proportional to the fiber content of the diet that is used to produce acetate in the synthesis of milk fat in the mammary gland (Oliveira et al., 1999). Silva et al. (2009) did not verify the influence of the levels of 0,1 , 3 and $5 \mathrm{~kg}$ of concentrated cow/day in the diet of crossbred cows kept in pasture on the constituents of milk (fat: $2.32 ; 2.45 ; 2.34$ and $2.25 \%$ ) and (protein: 3.14; 3.08; 2.99 and $3.22 \%$ ).

It was noted in Table 5, the increase of milk protein from cow's percentage of PDSP treatments, PDCS and PCS, which was increased, and the linear equation was the best fit to occur. This increase is directly linked to the better protein intake of the diets offered. The composition of milk from cows that received the PDSS nutritional plan, which remained constant, can be explained by the lower protein intake.

The increase in milk protein content is directly involved with the consumption of concentrate, which causes an increase in the production of propionic acid in the rumen, which in turn increases the availability of amino acids to the mammary gland, due to the lower use of these in the process of neoglucogenesis and also related to food that has an effect on the microbial synthesis in the rumen (Deresz, 2001). The alteration of milk fat and protein should be the object of attention, since milk that presents values higher than that described in mAPA Normative Instruction 62, which stipulates a minimum content of $3.0 \%$ of fat and $2.9 \%$ of protein in milk (Brasil, 2011) may receive bonus from the industry through extra payment to producers.

The percentage of lactose in the milk of cows that received only deferred pasture with concentrated feed according to production was higher $(\mathrm{P}<0.05)$ than the percentage of lactose in the milk of cows from other treatments. This may be correlated with the lower protein intake of the diet offered. Results were reported by Fukumoto et al. (2010) who found average lactose content of $4.26 \%$. When the lactose behavior was verified in function of the days of experimental collection, in treatment two, deferred pasture plus protein, an increase in its percentage was observed, and the increasing linear equation was the one that best adjusted to the results. There was no difference in the other treatments. 
Effect of protein...

Table 5. Milk composition of F1 1/2 Holstein x 1/2 Zebu cows fed different nutritional plans and days under evaluation

\begin{tabular}{|c|c|c|c|c|c|c|c|c|}
\hline \multirow{2}{*}{ Item } & \multicolumn{6}{|c|}{ Days under evaluation } & \multirow{2}{*}{$\mathrm{CV}(\%)$} & \multirow{2}{*}{ P-value } \\
\hline & 1 & 8 & 15 & 22 & 29 & 36 & & \\
\hline \multicolumn{9}{|c|}{ Protein, \% } \\
\hline PDSS & 2.91 & 2.88 & 3.04 & 3.07 & 3.06 & 3.05 & 7.43 & NS \\
\hline $\mathrm{PDCS}^{1}$ & 3.00 & 3.17 & 3.32 & 3.30 & 3.32 & 3.31 & 9.77 & 0.04 \\
\hline $\mathrm{PDSP}^{2}$ & 2.97 & 3.14 & 3.26 & 3.26 & 3.31 & 3.30 & 6.23 & $<0.01$ \\
\hline $\mathrm{SMP}^{3}$ & 3.04 & 3.29 & 3.34 & 3.42 & 3.49 & 3.44 & 6.89 & $<0.01$ \\
\hline \multicolumn{9}{|c|}{ Fat, \% } \\
\hline PDSS & 3.95 & 3.91 & 3.88 & 4.06 & 3.97 & 4.00 & 12.64 & NS \\
\hline PDCS & 4.03 & 4.02 & 3.81 & 3.96 & 3.61 & 3.65 & 17.12 & NS \\
\hline PDSP & 3.97 & 3.71 & 3.86 & 3.81 & 3.70 & 3.82 & 14.35 & NS \\
\hline SMP & 4.78 & 4.63 & 4.48 & 4.15 & 4.39 & 4.44 & 19.84 & NS \\
\hline \multicolumn{9}{|c|}{ Lactose \% } \\
\hline PDSS & 4.67 & 4.64 & 4.59 & 4.59 & 4.65 & 4.61 & 4.15 & NS \\
\hline $\mathrm{PDCS}^{4}$ & 4.64 & 4.57 & 4.56 & 4.48 & 4.50 & 4.49 & 3.26 & 0.02 \\
\hline PDSP & 4.61 & 4.57 & 4.56 & 4.48 & 4.50 & 4.49 & 5.59 & NS \\
\hline SMP & 4.67 & 4.66 & 4.69 & 4.73 & 4.69 & 4.76 & 3.48 & NS \\
\hline \multicolumn{9}{|c|}{ Defatted dry extract, \% } \\
\hline PDSS & 8.58 & 8.76 & 8.63 & 8.64 & 8.69 & 8.67 & 4.05 & NS \\
\hline PDCS & 8.64 & 8.75 & 8.87 & 8.76 & 8.80 & 8.78 & 4.24 & NS \\
\hline PDSP & 8.58 & 8.77 & 8.75 & 8.71 & 8.72 & 8.71 & 4.39 & NS \\
\hline $\mathrm{SMP}^{5}$ & 8,69 & 8,9 & 8,98 & 9,12 & 9,14 & 9,16 & 3,59 & 0.01 \\
\hline \multicolumn{9}{|c|}{ Total dry extract, \% } \\
\hline PDSS & 12.48 & 12.55 & 12.52 & 12.74 & 12.68 & 12.60 & 5.40 & NS \\
\hline PDCS & 12.67 & 12.77 & 12.68 & 12.73 & 12.42 & 12.43 & 6.42 & NS \\
\hline PDSP & 12.56 & 12.37 & 12.61 & 12.56 & 12.42 & 12.53 & 5.46 & NS \\
\hline SMP & 13.47 & 13.53 & 13.46 & 13.33 & 12.54 & 13.60 & 6.23 & NS \\
\hline \multicolumn{9}{|c|}{ Milk urea nitrogen, $m g / d L$} \\
\hline $\mathrm{PDSS}^{6}$ & 10.63 & 6.55 & 4.77 & 7.88 & 7.22 & 6.85 & 27.95 & $<0.01$ \\
\hline PDCS & 8.41 & 8.83 & 8.88 & 9.72 & 9.36 & 8.13 & 21.07 & NS \\
\hline $\mathrm{PDSP}^{7}$ & 11.73 & 8.97 & 10.67 & 11.68 & 10.92 & 8.78 & 23.04 & $<0.01$ \\
\hline SMP & 12.36 & 13.52 & 8.31 & 13.22 & 13.63 & 12.32 & 19.65 & NS \\
\hline \multicolumn{9}{|c|}{ Somatic cell count, $x$ 1000/mL } \\
\hline $\mathrm{PDSS}^{8}$ & 152.00 & 104.37 & 78.50 & 133.1 & 71.50 & 75.50 & 13.71 & 0.02 \\
\hline $\mathrm{PDCS}^{9}$ & 142.25 & 134.00 & 64.00 & 89.25 & 82.00 & 67.00 & 10.69 & $<0.01$ \\
\hline $\mathrm{PDSP}^{10}$ & 120.75 & 143.12 & 50.12 & 66.87 & 52.87 & 282.37 & 18.51 & 0.02 \\
\hline $\mathrm{SMP}^{11}$ & 181.25 & 320.12 & 169.8 & 109.6 & 130.7 & 95.25 & 32.78 & 0.02 \\
\hline
\end{tabular}

PDSS - Deferred pasture as a source of roughage without supplementation; PDCS - Deferred pasture as a source of roughage with protein supplement offer; PDSP - deferred pasture supplemented with 15 kilos of corn silage (natural base) + 1,200 grams of protein supplement; SMP - corn silage (ad libitum) +700 grams of protein supplement.

${ }^{1} \hat{Y}=3.09+0.08 X, R^{2}=0.67 ;{ }^{2} \hat{Y}=3,04+0.09 \mathrm{X}, R^{2}=0.79 ;{ }^{3} \hat{Y}=3.13+0.011 X, R^{2}=0.79 ;{ }^{4} \hat{Y}=4.62-0.04 X, R^{2}=0.80$;

${ }^{5} \hat{Y}=8.75+0.013 \mathrm{X}, \mathrm{R}^{2}=0.89 ;{ }^{6} \hat{\mathrm{Y}}=11.74-1.12 \mathrm{X}+0.06 \mathrm{X}^{2}, \mathrm{R}^{2}=0.87 ;{ }^{7} \hat{\mathrm{Y}}=12.1079-0.62417 \mathrm{X}+0.046166 \mathrm{X}^{2}$, $\mathrm{R}^{2}=0.87 ;{ }^{8} \hat{\mathrm{Y}}=134.70-1.17 \mathrm{X}, \mathrm{R}^{2}=0.49 ;{ }^{9} \hat{\mathrm{Y}}=134.70-2.06 \mathrm{X}, \mathrm{R}^{2}=0.61 ;{ }^{10} \hat{\mathrm{Y}}=77.51+2.26 \mathrm{X}, \mathrm{R}^{2}=0.43 ;{ }^{11} \hat{\mathrm{Y}}=247.69-$ $4,31 \mathrm{X}, \mathrm{R}^{2}=0.89$

NS: not significant.

CV- Coefficient of variation

P- Probability

The defatted dry extract (ESD) and total dry extract were superior for the treatment cows that received more concentrated and lower corn silage for the other treatments. These data are directly related to the protein and fat content of milk from cows that received diets whose roughage used was corn silage. The percentage of the ESD as a function of the days of experimental collection, in the SMP treatment, more concentrated silage, showed an increase in 
its percentage and the increasing linear equation was the one that best adjusted to the results. In the other treatments, there was no significant difference.

The concentration of milk urea nitrogen (MUN) observed was higher in milk from SMP treatment cows, followed by milk from PDCS, PDSP treatment cows, and the lowest value for milk from cows in the PDSS nutritional plan. The concentrations of MUN reflected the protein content of the diets, within the limit considered normal for milk from SMP treatment cows and below normal for milk from other treatments, since the literature reports that normality is when the MUN is found between 10 and $17 \mathrm{mg} / \mathrm{dL}$ (Borges et al., 2019). Values outside this range reflect inadequate nutritional management, especially with regard to dietary protein. The MUN levels, depending on the days of evaluation, showed unstable behavior. The fact may be due to a nutritional imbalance between energy and protein, which alters nitrogen excretion. Fike et al. (2003) found that cows supplemented with a higher amount of concentrate had lower MUN content in milk.
The authors explained that this was due to the greater availability of energy in the rumen, lower value for N-NH3 in the rumen fluid and greater milk production. The values found for SCC are within the recommended for good quality milk less than 200,000 cells $/ \mathrm{mL}$ and were similar (P> 0.05 ) between treatments, which indicates that the health of the gland was normal and, therefore, did not interfere in production. A reduction in the number of cells depending on the days of collection was found in all treatments, which is demonstrated by the decreasing linear equations. Alhussien and Dang (2018) reported that the somatic cell variations present in milk are mainly due to deficiencies in milking management practices, the number and lactation stage of milked animals, and climatic variations have little influence on the health of the mammary gland. In the Table 6 describes the evaluations of the weights of cows and calves at the beginning and end of the experiment. It is observed that the cows in the SMP treatment maintained weight, while the cows in the other groups lost $(\mathrm{P}<0.01)$, and for the calf weight all gained in a similar way. The residual milk was sufficient to increase the calf's weight during the experimental period.

Table 6 . Body performance of F1 1/2 Holstein x $1 \frac{1}{2}$ Zebu cows and calves fed different Nutritional plans

\begin{tabular}{|c|c|c|c|c|}
\hline \multirow[b]{2}{*}{ Item } & \multicolumn{4}{|c|}{ Nutritional plans } \\
\hline & PDSS & PDCS & PDSP & SMP \\
\hline & \multicolumn{4}{|c|}{ Cows performance } \\
\hline Initial body weight & $552.2 \mathrm{a}$ & $569.9 \mathrm{a}$ & $559.6 \mathrm{a}$ & $513.4 \mathrm{a}$ \\
\hline Final body weight & $501.9 \mathrm{~b}$ & $548.7 \mathrm{a}$ & $546.9 \mathrm{a}$ & $519.5 \mathrm{~b}$ \\
\hline Weight gain differential (kg) & $-50.3 c$ & $-21.2 b$ & $-12.7 b$ & $6.1 \mathrm{a}$ \\
\hline \multirow{2}{*}{ Weight gain, $\%$} & -9.10 & -3.71 & -2.26 & 1.18 \\
\hline & \multicolumn{4}{|c|}{ Calf performance } \\
\hline Initial body weight & $66.0 \mathrm{a}$ & $74.7 \mathrm{a}$ & $74.7 \mathrm{a}$ & $70.4 \mathrm{a}$ \\
\hline Final body weight & $80.1 \mathrm{c}$ & $89.7 \mathrm{a}$ & $91.7 \mathrm{a}$ & $86.4 b$ \\
\hline Weight gain differential (kg) & $14.1 \mathrm{a}$ & $15.0 \mathrm{a}$ & $17.0 \mathrm{a}$ & $16.0 \mathrm{a}$ \\
\hline Weight gain, $\%$ & 21.36 & 20.08 & 22.75 & 22.72 \\
\hline
\end{tabular}

When the cows were in the adaptation period to the diet, they were around $66.3(\mathrm{P}>0.05)$ days post-partum, at the beginning of the experiment they had $88.34(\mathrm{P}>0.05)$ days, that is, after the average peak of production, which occurs at 40 days (Ruas et al., 2014). The service period for the cows of all treatments was evaluated and the average obtained was 84.13 days ( $\mathrm{P}>0.05$ ), which represents an estimated annual fertility rate of $98.0 \%$ of this herd.

\section{CONCLUSION}

F1 Holstein/Zebu cows handled in deferred pasture in a traditional way supplemented with protein keeps average daily production of 
$11.76 \mathrm{~kg}$ of milk with normal composition. Failure to supplement deferred pasture with protein causes a decline in milk production and accentuates cows' weight loss.

\section{ACKNOWLEDGMENTS}

The authors thank the Finep and MCTI for financial support $\mathrm{n}^{\circ}$ 1334/13 and INCT - Ciência Animal. Gratitude is also extended to Epamig and Foundation for Research Support of the State of Minas Gerais (FAPEMIG) for their financial support (PPM 00265-18) and the National Council for Scientific and Technological Development $(\mathrm{CNPq})$. This study was financed in part by the Coordenação de Aperfeiçoamento de Pessoal de Nível Superior - Brasil (CAPES) Finance Code 001.

\section{REFERENCES}

ALHUSSIEN, M.N.; DANG, A.K. Milk somatic cells, factors influencing their release, future prospects, and practical utility in dairy animals: an overview. Vet. World, v.11, p.562-577, 2018.

BORGES, L.D.A.; ROCHA JÚNIOR, V.R.; MONÇÃO, F.P. et al. Nutritional and productive parameters of Holstein/Zebu cows fed diets containing cactus pear. Asian-Australas. J. Anim. Sci., v.32, p.1373-1380, 2019.

BORGES, LA.; RUAS, J.R.M.; ROCHA JÚNIOR, V.R. et al. Effects of short-term feed restriction on the physiological parameters and metabolites of $\mathrm{F} 1$ Holstein $\mathrm{x}$ Zebu cows in different stages of lactation. Arq. Bras. Med. Vet. Zootec., v.72, p.1545-1554, 2020.

BRASIL. Ministério de Agricultura, Pecuária e Abastecimento. Instrução Normativa $\mathrm{N}^{\circ}$ 62, de 29 de dezembro de 2011. Diário Oficial da União, 30 dezembro 2011.

DANES, M.A.C.; CHAGAS L.J.; PEDROSO, A.M. et al. Effect of protein supplementation on milk production and metabolism of dairy cows grazing tropical grass. J. Dairy Sci., v.96, p.401$418,2013$.

DERESZ, F. Produção de leite de vacas mestiças Holandês $x$ Zebu em pastagem de capimelefante, manejada em sistema rotativo com e sem suplementação durante a época de chuvas. Rev. Bras. Zootec., v.30, p.197-204, 2001.
DETMANN, E.; SOUZA, M.A.; VALADARES FILHO, S.C. Métodos para análise de alimentos. Fortaleza: Suprema, 2012. 214p.

FIKE, J.H.; STAPLES, C.R.; SOLLENBERGER, L.E. et al. Pasture forages, supplementation rate and stocking rate effects on dairy cow performance. J. Dairy Sci., v.86, p.268-1281, 2003.

FUKUMOTO, N.M.; DAMASCENO, J.C.; DERESZ, F., et al. Produção e composição do leite, consumo de matéria seca e taxa de lotação em pastagens de gramíneas tropicais manejadas sob lotação rotacionada. Rev. Bras. Zootec., v.39, p.1548-1557, 2010.

MISHRA, S.; KUMARI, K.; DUBEY, A. Body condition scoring of dairy cattle: a review. research \& reviews: J. Vet. Sci., v.2, p.58-65, 2016.

MONÇÃO, F.P.; COSTA, M.A.M.; RIGUEIRA, J.P. et al. Yield and nutritional value of BRS Capiaçu grass at different regrowth ages. Semin. Ciênc. Agrár., v.40, p.2045-2056, 2019.

MONÇÃO, F.P.; COSTA, M.A.M.; RIGUEIRA, J.P. et al. Productivity and nutritional value of BRS capiaçu grass (Pennisetum purpureum) managed at four regrowth ages in a semiarid region. Trop. Anim. Health Prod., v.51, p.1-7, 2020.

MOTT, G.O.; LUCAS, H.L. The desing, conduct, and interpretation of grazing trials on cultivated and improved pastures. In: INTERNATIONAL GRASSLAND CONGRESS, 6., 1952, Pennsylvania. Proceedings... Pennsylvania: [s.n.], 1952. p.1380-1385.

NUTRIENT requeriments of dairy cattle. 7.rev.ed. Washington: National Research Council, 2001. 381p.

OLIVEIRA, C.A.F.; FONSECA, L.F.L.; GERMANO, P.M.L. Aspectos relacionados à produção, que influenciam a qualidade do leite. Hig. Aliment., v.13, p.10-16, 1999.

RUAS, J.R.M.; SILVA, E.A.; QUEIROZ, D.S. et al. Características produtivas da lactação de quatro grupos genéticos F1 Holandês x Zebu. Rev. Bras. Ciênc. Vet., v.21, p.33-37, 2014. 

$\begin{array}{lll}\text { SALGADO, L.F.F.; } & \text { CRUZ, T.M.S.; } \\ \text { TAKATANI, H. A Raça Girolando: } & \text { história, }\end{array}$ evolução e importância no cenário da pecuária leiteira nacional. Boletim técnico 19, Deacalvado: UNIBRASIL, 2016, 14p. 14p. (Boletim Técnico da Universidade Brasil, Departamento de Produção Animal, n.19).

SAMPAIO, R.L.; REIS, F.D.; OLIVEIRA, R.A. et al. The nutritional interrelationship between the growing and finishing phases in crossbred cattle raised in a tropical system. Trop. Anim. Health Prod., v.49, p.1015-1024, 2017.

SANTANA, PF. et al. Nutritional, behavioral and performance parameters of $\mathrm{F} 1$ Holstein $\mathrm{x}$ Zebu cows at different lactation stages. Arq. Bras. Med. Vet. Zootec., v.72, p.1469-1478, 2020.

SANTANA, PF.; ROCHA JÚNIOR, V.R.; RUAS, J.R.M. et al. Feed restriction of F1 Holstein $\times$ Zebu cows in the final third of lactation modifies intake, nutrient digestibility, feeding behavior, and performance. Rev. Bras. Zootec., v.48, e20180130, 2019.

SANTOS, M.E.R.; FONSECA, D.M.; BALBINO, EM. et al. Caracterização dos perfilhos em pastos de capim-braquiária diferidos e adubados com nitrogênio. Rev. Bras, Zootec., v.38, p.643-649, 2009.

SHEAHAN, A.J.; GIBBS, S.J.; ROCHE, J.R. Timing of supplementation alters grazing behavior and milk production response in dairy cows. J. Dairy Sci., v.96, p.477-483, 2013.
SILVA, C.V.; LANA, R.P.; CAMPOS, J.M.S. et al. Consumo, digestibilidade aparente dos nutrientes e desempenho de vacas leiteiras em pastejo com dietas com diversos níveis de concentrado e proteína bruta. Rev. Bras. Zootec., v.38, p.1372-1380, 2009.

SILVA, J.A.; SILVA, C.B.M.; SOUSA, D.P. et al. Supplementation strategies for dairy cows kept in tropical grass pastures. Semin. Ciênc. Agrár., v.38, p.401-416, 2017.

SKLAN, D.; ASHKENAZI, R.; BRAUN, A. et al. Fatty acids, calcium soaps of fatty acids and cottonseeds fed to high yielding cows. J. Dairy Sci., v.75, p.2463-2472, 1992.

TEIXEIRA, R.M.A.; MARTINS, J.M.; SILVA, N.G.; SILVA, E.A. Suplementação proteica de vacas leiteiras mantidas em pastagem de Tifton 85 durante o período de seca. Arq. Bras. Med. Vet. Zootec., v.71, p.1027-1036, 2019.

VALADARES FILHO, S. C., COSTA E SILVA, L. F., LOPES, S. A. et al. BR-CORTE 3.0. Cálculo de exigências nutricionais, formulação de dietas e predição de desempenho de zebuínos puros e cruzados. 2016. Disponível em www.brcorte.com.br.

WITTWER, F. Diagnóstico dos desequilíbrios metabólicos de energia. In: GONZALEZ, F.H.D.; BARCELLOS, J.O.; OSPINA, H. et al. Perfil metabólico em ruminantes: seu uso em nutrição e doenças nutricionais. Poto Alegre: Felix, H.D., 2000. p.9-22. 